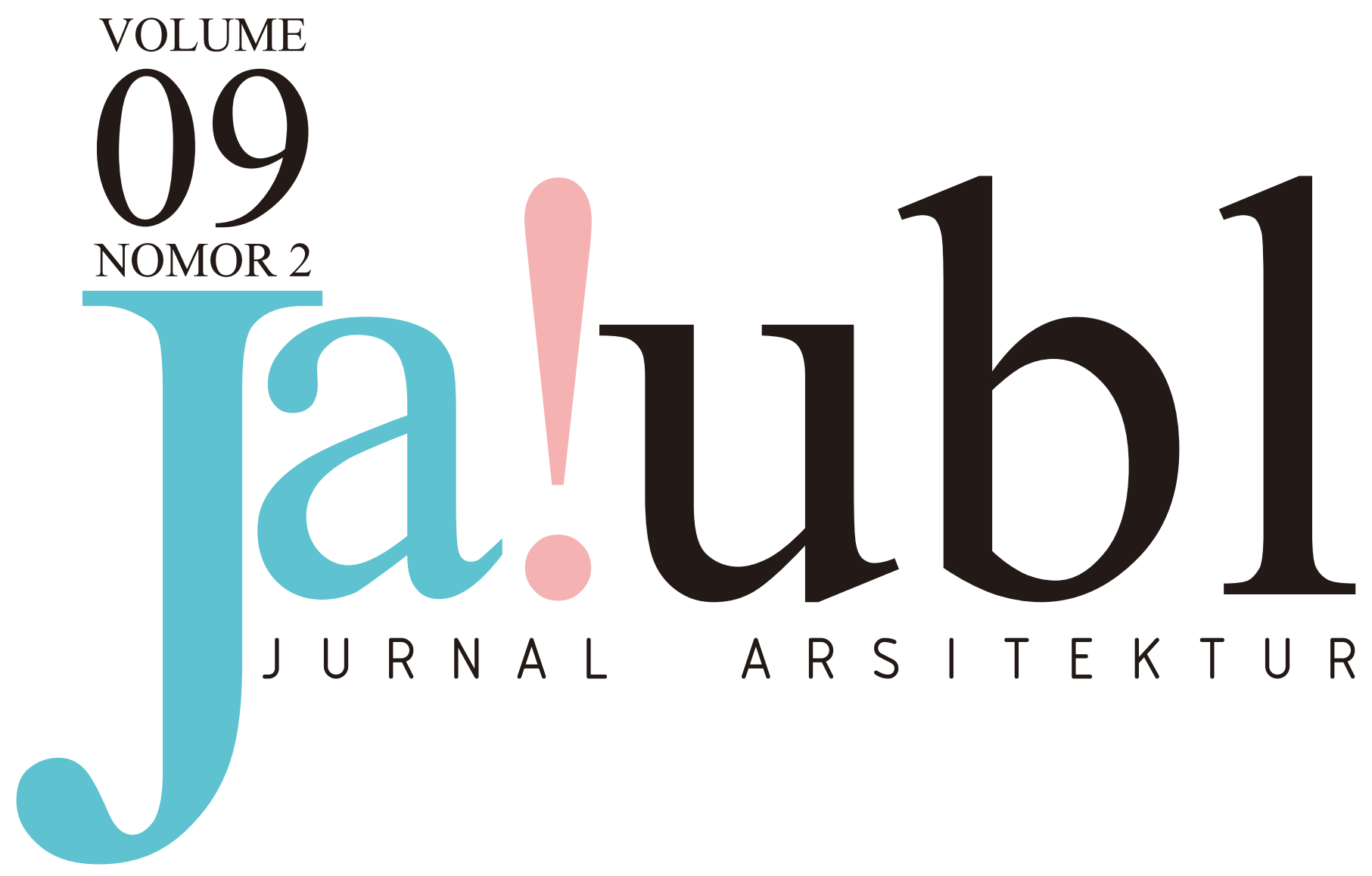


JA!UBL - Jurnal Arsitektur

Terbit dua kali setahun pada bulan Januari dan Juli. Diterbitkan oleh Program Studi Arsitektur Fakultas Teknik Universitas Bandar Lampung. JA!UBL merupakan media pendokumentasian, sharing, dan publikasi karya ilmiah yang berisi karya-karya riset ilmiah mengenai bidang ilmu perancangan arsitektur dan bidang ilmu lain yang sangat erat kaitannya seperti perencanaan kota dan daerah, desain interior, perancangan lansekap, dan sebagainya.

ISSN: 2087-2739

\section{PELINDUNG}

Dr. Ir.H.M.Yusuf Barusman, M.B.A. (Universitas Bandar Lampung)

\section{PENASEHAT}

Dr. Ir. Hery Riyanto, M.T. (Universitas Bandar Lampung)

PENANGGUNG JAWAB

Ir. Tjetjeng Sofjan S., M.M., M.T. (Universitas Bandar Lampung)

\section{PIMPINAN REDAKSI}

Dr.Eng. Haris Murwadi, S.T., M.T.

\section{REDAKSI PELAKSANA}

Shofia Islamia Ishar, S.T., M.T.

Dadang Hartabela, S.T., M.T.

Ai Siti Munawaroh, S.Pd., M.I.L.

Indyah Kumoro Wardani, S.T., IAI

\section{DEWAN REDAKSI}

Prof. Dr. Julaihi Wahid (Universitas Sains Malaysia)

Prof. Dr. Ir. H. Slamet Tri Sutomo, M.S (Universitas Hasanuddin)

Prof. Ir. Totok Rusmanto, M.Eng. (Universitas Diponegoro)

Prof. Dr. Ing. Ir Gagoek Hardiman. (Universitas Diponegoro)

Dr.Eng. Fritz Akhmad Nuzir, S.T., M.A.(L.A.) (Universitas Bandar Lampung)

David Hutama, ST., M.Eng (Universitas Pelita Harapan)

\section{MITRA BESTARI}

Dr. Ir. Budi Prayitno, M.Eng. (Universitas Gajah Mada)

Dr. Eng. Ir. Ahmad Sarwadi, M.Eng (Universitas Gajah Mada)

Prof. Dr. T. Yoyok Wahyu Subroto, M.Eng. Ph. D. (Universitas Gajah Mada)

Dr.Eng. Fritz Akhmad Nuzir, S.T., M.A. (L.A.) (Universitas Bandar Lampung)

Prof. Ir. Liliany Sigit Arifin, M.Sc., Ph. D (Universitas Petra)

Dr. Budi Faisal (Institut Teknologi Bandung)

Dr.Eng. Agus Hariyadi, S.T., M.Sc. (Universitas Gajah Mada)

\section{TIM GRAFIS DESAIN}

Satrio Agung Perwira

B. Chrysvania Artemisia

\section{ALAMAT REDAKSI}

Program Studi Arsitektur Fakultas Teknik Universitas Bandar Lampung

Jalan Zainal Abidin Pagar Alam Nomor. 26 Labuhanratu, Bandarlampung, 35142

Telp. $\quad:$ :0721-773847

E-mail : : editor.j@ubl.ac.id

Homepage : ubl.ac.id 


\section{Daftar Isi Artikel}

01-06 Analisis Penerapan Art Deco pada Rumah di Bandung Periode Perang Dunia I-II Studi Kasus: Tiga Villa dan Perumahan Dosen UPI FADILASARI, Dewi

07-12 Tipologi Bentuk Atap pada Arsitektur Jawa ROOSANDRIANTINI, Josephine; SANTOSO, Angelina Novemita; AMBARWATI, Catherina Novita

13-18 Identifikasi Respon Pengunjung mengenai Keberadaan Desa Wisata Taman Purbakala Pugungraharjo Lampung HARTABELA, Dadang; MASITO, Yuni

19-26 Fenomena Terbentuknya Ruang Spatio-Temporal di Kawasan Stadion Pahoman Bandarlampung WIBAWA, M. Shubhi Yuda

27-32 Identifikasi Area Berpotensi Macet di Kawasan Pendidikan Jl. Z.A. Pagar Alam Bandarlampung PERWIRA, Satrio Agung; MURWADI, Haris; MUNAWAROH, Ai Siti; ISHAR, Shofia Islamia

33-40 Manfaat Ruang Terbuka dan Hubungannya dengan Kegiatan Interaksi Sosial Studi Kasus: Perumahan Nusa Tamalanrea Indah Makassar NURHIJRAH; WIKANTARIA, Ria 


\title{
Manfaat Ruang Terbuka dan Hubungannya dengan Kegiatan Interaksi Sosial Studi Kasus: Perumahan Nusa Tamalanrea Indah Makassar
}

\author{
Nurhijrah $^{1 *}$, Ria Wikantaria ${ }^{2}$ \\ ${ }^{1}$ Program Studi Tenik Sipil, Fakultas Teknik, Universitas Andi Djemma Palopo \\ ${ }^{2}$ Departemen Arsitektur, Fakultas Teknik, Universitas Hasanuddin \\ *Penulis Korespondensi: nurhijrah.rie@unanda.ac.id; Telp. +62 821-3263-8431
}

\begin{abstract}
Abstrak
Penelitian ini bertujuan untuk mengidentifikasi karakteristik ruang terbuka, kegiatan interaksi sosial masyarakat di ruang terbuka, dan hubungan antara ruang terbuka dan kegiatan interaksi pada Perumahan Nusa Tamalanrea Indah di Makassar. Pengumpulan data dilakukan dengan survei lokasi, teknik angket dengan 42 sampel pelaku kegiatan interaksi, dan dokumentasi kegiatan masyarakat perumahan tersebut untuk kemudian dianalisis dengan metode deskriptif dengan jenis data kualitatif dan kuantitatif. Kesimpulan yang didapatkan bahwa karakteristik ruang terbuka yang digunakan untuk melakukan kegiatan interaksi yaitu: 1) Letaknya di depan rumah, halaman masjid, tepi taman, jalan dan tanah kosong, jaraknya dari rumah sekitar 0-100 m dengan luasan ruang terbuka yang dominan digunakan ialah sekitar 0-12 $\mathrm{m}^{2}$, serta perabot ruang terbuka seperti: lampu taman dan tempat duduk dan pohon peneduh. 2) Kegiatan interaksi seperti: bercerita, bermain, menelpon dan bertransaksi jual beli. Adapun intensitas kegiatan interaksi yang dilakukan ialah dominan beberapa kali seminggu dengan durasi kegiatan sekitar 15-30 menit. 3) Variabel karakteristik ruang terbuka dan karakteristik responden yang signifikan bepengaruh terhadap terjadinya interaksi sosial ialah letak ruang terbuka tersebut, jarak ruang terbuka dari rumah, luasan ruang terbuka dan perabot ruang terbuka. Dari hasil penelitian, disarankan untuk mengelola kembali ruang terbuka yang sudah ada dan lengkapi dengan fasilitas, agar interaksi warga dapat berjalan dengan lebih baik.
\end{abstract}

Kata Kunci: interaksi social; ruang terbuka; perumahan

\section{Latar Belakang}

Ruang terbuka publik adalah ruang tidak terbangun yang berfungsi untuk meningkatkan kualitas estetika, lingkungan, dan kesejahteraan warganya. Carr (1992) dalam bukunya Public Space, menyatakan bahwa ruang terbuka publik harus responsif, demokratis dan bermakna. Responsif artinya ruang terbuka publik harus dapat digunakan untuk berbagai kegiatan dan kepentingan luas. Demokratis berarti ruang terbuka publik seharusnya dapat digunakan oleh masyarakat umum dari berbagai latar belakang sosial, ekonomi dan budaya serta aksesibel bagi penyandang cacat tubuh, lanjut usia dan berbagai kondisi fisik manusia. Sedangkan bermakna berarti ruang terbuka publik harus memiliki tautan dengan manusia, dunia luas, dan konteks sosial.

Ruang terbuka yang yang kian lama menjadi sempit. Hal ini membuat masyarakat umum semakin sulit mengakses ruang bersama. Ketidakberadaan ruang publik ini adalah bencana tidak langsung yang pada akhirnya akan mengkotak-kotakkan masyarakat dengan sikap egoistis dan individualistik, dengan sendirinya akan menghilangkan rasa kebersamaan yang menjadi ciri khas masyarakat masyarakat timur.

Dalam penelitian ini dilakukan eksplorasi dari suatu produk arsitektur perumahan, yaitu Perumahan Nusa Tamalanrea Indah Makassar. Lokasi yang dipilih dengan pertimbangan perumahan NTI merupakan perumahan menengah kecil yang masyarakatnya merupakan masyarakat golongan menengah ke bawah dimana masyarakat tersebut masih memelihara perasaan kebersamaan dalam komunitas, relasi, dan interaksi yang didasari oleh transkasi sosial daripada motif ekonomi, serta memiliki ruang privasi yang lebih longgar (Youngenteb dalam Barliana: 2010).

Adapun tujuan dari penelitian ini adalah Untuk mengidentifikasi karakteristik ruang terbuka yang biasa digunakan oleh masyarakat NTI untuk kegiatan interaksi. Untuk mengidentifikasi kegiatan interaksi seperti apa saja yang dilakukan masyarakat perumahan NTI di ruang terbuka dan untuk menemupahami sejauhmana hubungan karakteristik ruang terbuka yang ada pada perumahan terhadap interaksi social.

\section{Metode}

Metode yang digunakan untuk kepentingan dalam pengumpulan data penelitian ini adalah dengan metoda deskriptif. Penelitian deskriptif ini adalah penelitian yang bermaksud untuk membuat deskripsi mengenai situasi-situasi atau kejadian-kejadian (Suryabrata, 1987). Deskriptif data tersebut dikumpulkan dengan cara 
melakukan survei lokasi, teknik angket, dokumentasi, dan studi literature. Populasinya yaitu masyarakat penguna ruang terbuka di Perumahan NTI dan jumlah sampel yang didapakan ialah 42 orang.

\section{Hasil dan Pembahasan}

\subsection{Deskripsi Perumahan Nusa Tamalanrea Indah Makassar}

Kota Makassar yang kini kian maju tidak bisa disangkal lagi dengan banyaknya fasilitas publik yang dibangun mulai dari mall-mall, hotel, pusat bisnis, perumahan dan perkantoran. Sebagai pintu gerbang Indonesia Timur, Makassar merupakan salah satu kota besar yang berpotensi menjual properti tertinggi. Di sisi ekonomi, laju pertumbuhan ekonomi kota ini berada di peringkat paling di Indonesia. Dalam lima tahun terakhir, rata-rata pertumbuhan ekonomi di Kota Makassar di atas sembian persen dan daya pembelian propertinya pun meningkat. Masuknya pengembang nasional ke Makassar membuat investasi properti semakin maju hingga angka kebutuhan perumahan mencapai enam ribu unit pertahunnya.

Perumahan Nusa Tamalanrea Indah, terletak pada kawasan pendidikan kota Makassar. Berdasarkan masterplan yang di rencanakan oleh pengembang (Gambar 1), saat ini perumahan NTI belum sepenuhnya selesai. Masih tersisa sekitar $30 \%$ pengerjaan hingga perumahan ini sepenuhnya selesai.

Pada pembangunan tahap pertama pada tahun 1995, jumlah rumah di NTI, sekitar 1.800 rumah, dan sekarang masih menjalani pembangunan tahap kedua yang rencananya berjumlah kurang lebih 3.000 rumah.
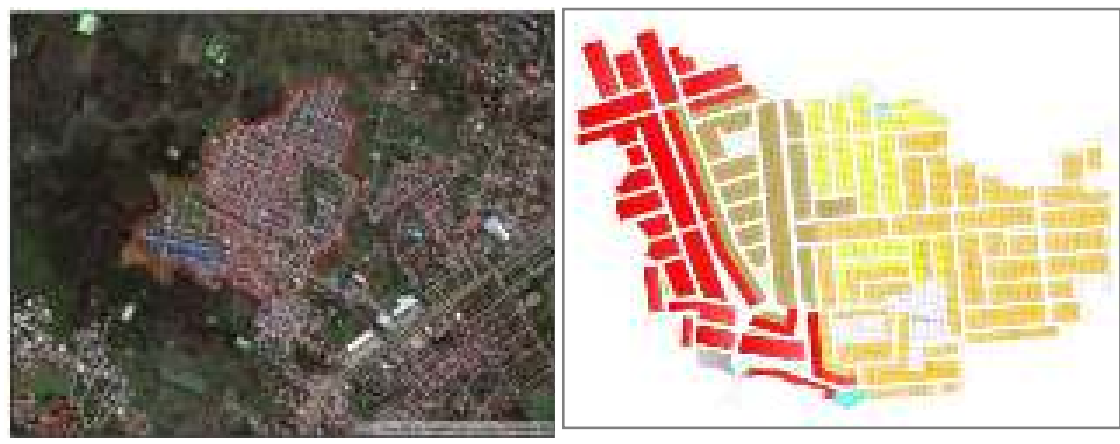

Gambar 1. Masterplan Perumahan Nusa Tamalanrea Indah Makassar

\subsection{Karakteristik Ruang Terbuka}

\subsubsection{Letak Ruang Terbuka}

Berdasarkan hasil pengamatan peneliti di lokasi penelitian yaitu di perumahan Nusa Tamalanrea Indah Makassar, didapatkan beberapa titik tempat masyarakat perumahan NTI melakukan interaksi sosial (lihat Gambar 2).

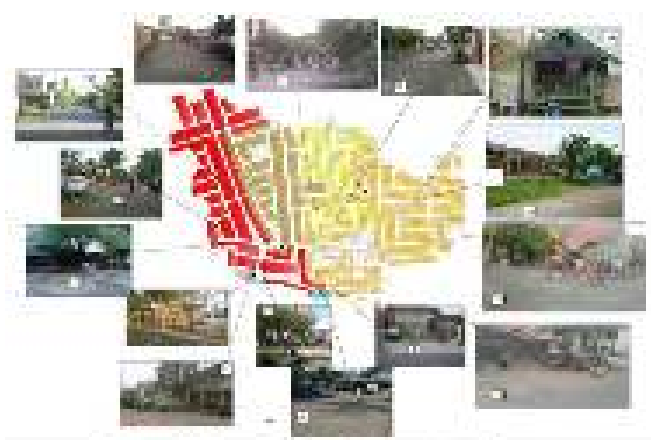

Gambar 2. Ruang Terbuka di Perumahan NTI

Berikut ini, terlebih dahulu diuraikan karakteristik setiap ruang terbuka yang digunakan oleh masyarakat:

1) Tepi Taman

Terdapat empat ruang terbuka hijau yang digunakan oleh masyarakat dengan karakteristik sebagai berikut:

Tepi Taman 1, terletak dibagian depan perumahan dengan luasan sekitar $48 \mathrm{~m}^{2}$, terdapat kegiatan jual-beli dari siang hari sampai sore hari. Area ini merupakan pusat perbelanjaan di daerah perumahan dan sifat ruang publik adalah responsif. Di warung ini para warga bersifat sebagai active engagement dan jenis interaksi yang terjadi antar warganya adalah interaksi individu dengan individu dengan jarak sosial dekat. 


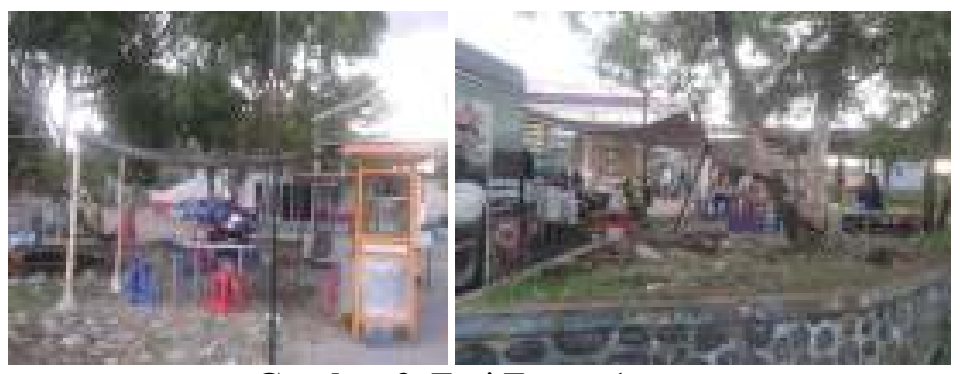

Gambar 3. Tepi Taman 1

Tepi Taman 2, terletak di bagian depan perumahan dan terdapat aktivitas perdagangan pada sore hari sampai malam hari.

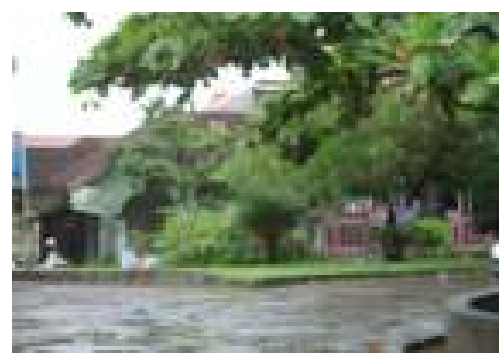

Gambar 4. Tepi Taman 2

Tepi Taman 3, terletak di bagian depan perumahan, tepatnya di depan kantor pemasaran perumahan, terdapat tempat duduk yang terbuat dari beton, dan tempat ini teduh karena terdapat beberapa pohon yang rindang.

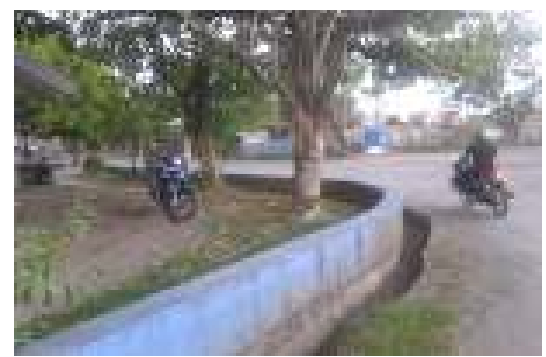

Gambar 5. Tepi Taman 3

Tepi Taman 4, terletak di area belakang perumahan, bentuknya memanjang dan terdapat tempat duduk yang terbuat dari beton.

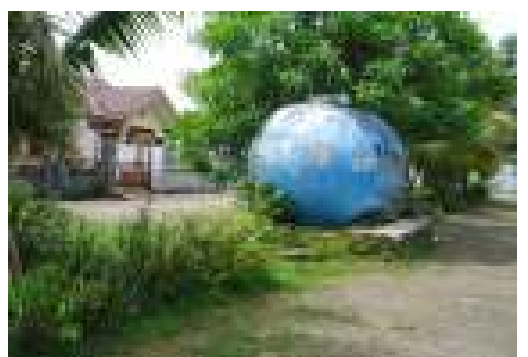

Gambar 6. Tepi Taman 4

\section{2) Jalan}

Kegiatan interaksi juga dilakukan di beberapa titik jalan perumahan, namun pada umunya karakteristik jalan di perumahan NTI sama yaitu: Jalan perumahan perkerasan dengan paving block beton dengan lebar jalan 8-10 m. Jalan merupakan ruang publik terbuka. Secara responsive, jalan dirancang sebagai alur sirkulasi. Tetapi, jalan disini bernilai meaningful karena dipakai berulang kali oleh anak-anak untuk bermain sepeda dan berlari-larian. Meskipun lebar jalan tidak cukup comfort untuk dilalui banyak orang, tetapi jalan ini dianggap cukup democratic bagi pengguna untuk berbagai macam kegiatan. 


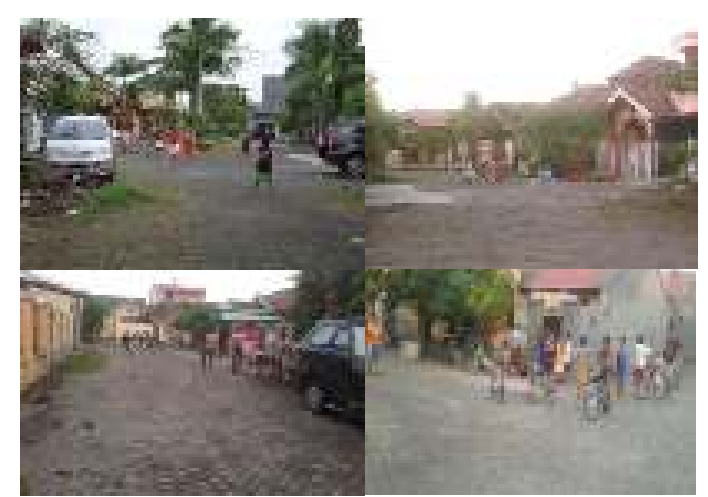

Gambar 7. Ruang terbuka Jalan

\section{3) Halaman Masjid}

Kegiatan interaksi juga terjadi di area masjid perumahan, karena pada masjid perumahan terdapat kegiatan TPA yang diikuti oleh anak-anak perumahan NTI. Terdapat dua tiitk tempat responden melakukan interaksi di area masjid, yaitu pada halaman masjid dan di depan masjid.

Halaman Masjid. Luasan sekitar $36 \mathrm{~m}^{2}$ dan ditutup dengan batako. Halaman masjid adalah ruang publik terbuka. Karena lahan yang terbatas, halaman masjid ini tidak cukup luas untuk menampung kegiatan masyarakat. Bangunan ini secara responsive difungsikan sebagai tempat peribadatan umat muslim. Selain itu, seringkali juga digunakan untuk kegiatan TPA warga sekitar. Saat pelaksanaan kegiatan keagamaan yang terjadi pada masjid tersebut adalah passive engagement dan setelah kegiatan selesai, di halaman masjid akan ditemui beberapa warga yang berbincang-bincang (active engagement).

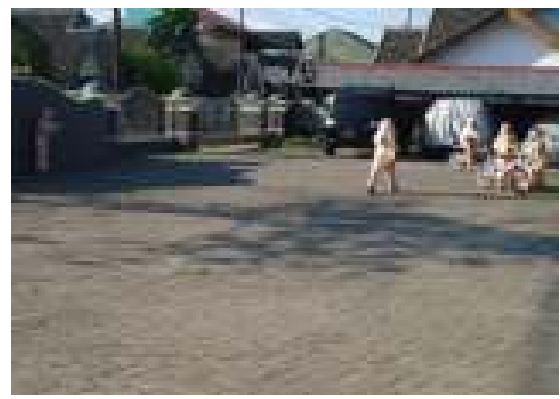

Gambar 8. Halaman Masjid

Depan Masjid. Kegiatan interaksi di depan masjid sebaliknya biasa dilakukan oleh anak laki-laki, dengan karakteristik: merupakan jalan perumahan, luasan yang digunakan sekitar $12 \mathrm{~m}^{2}$. Jalanan yang berpasir digunakan untuk bermain kelereng oleh anak-anak TPA dan sekitarnya.

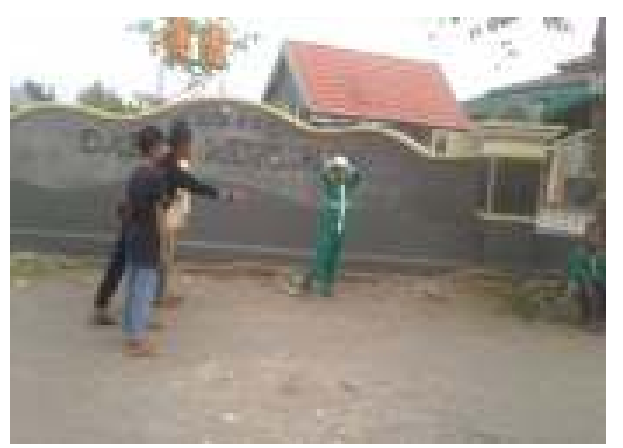

Gambar 9. Depan Masjid

\section{4) Depan Rumah}

Ruang terbuka didepan rumah yang digunakan masyarakat untuk melakukan interaksi sosial mempunyai karakteristik: terdapat tempat duduk di luar pagar rumah yang dapat digunakan untuk mengobrol dengan tetangga ataupun saudara. 


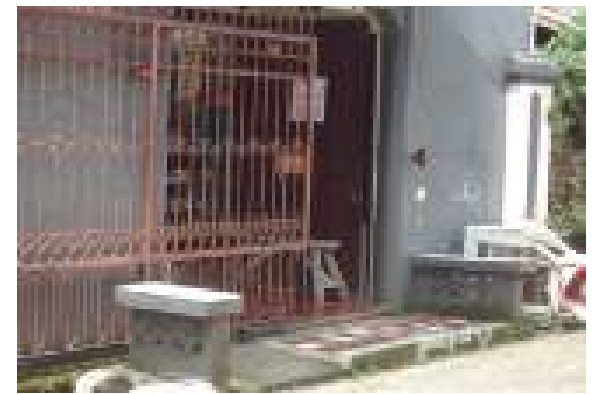

Gambar 10. Ruang terbuka depan rumah yang dilengkapi tempat duduk

Terdapat area kosong yang cukup luas yang biasanya digunakan anak-anak untuk bermain.

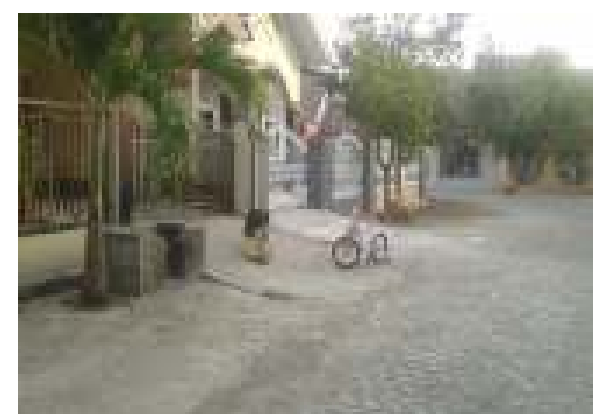

Gambar 11. Ruang terbuka depan rumah

Adapun terdapat permainan anak di depan rumah yang digunakan untuk berinteraksi dengan tetangga, teman bermain atau saudara. Sifat dari ruang publik ini ialah responsif.

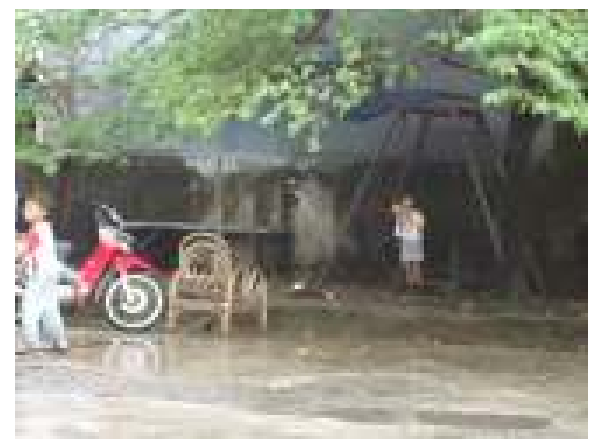

Gambar 12. Ruang terbuka yang dilengkapi dengan perabot anak

\section{5) Tanah Kosong}

Hanya terdapat satu titik ruang terbuka yang berupa tanah kosong yang digunakan untuk berinteraksi, yaitu dengan karakteristik: Tanah tertutup dengan beton dan terdapat pada sudut jalan sifat ruang publik ini adalah ruang publik terbuka yang tidak responsive. Ruang publik ini tidak bersifat comfort karena terbuka sehingga tidak terlindung dari panas matahari. Bagi beberapa masyarakat yang kerap menggunakannya, ruang terbuka ini dianggap meaningful karena hampir setiap hari pada lokasi tersebut ditemukan orang yang sama

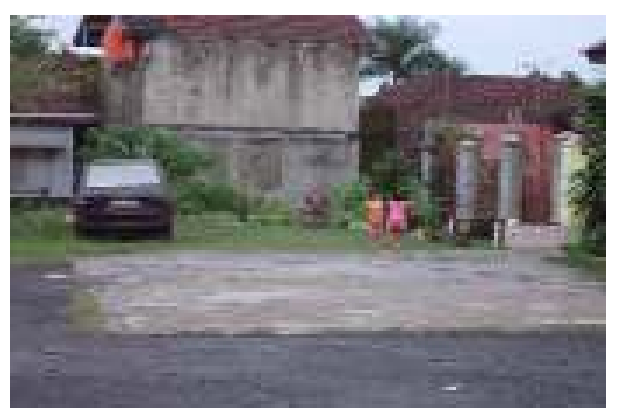

Gambar 13. Ruang Terbuka Tanah Kosong 


\subsubsection{Luasan Ruang Terbuka}

Ruang terbuka yang digunakan masyarakat Perumahan NTI untuk berinteraksi sosial memilki luasan yang beragam yang hal ini dipengaruhi dengan jumlah pengguna dan aktivitas yang dilakukan.

Berdasarkan hasil penelitian, didapatkan berbagai luasan ruang terbuka yang digunakan masyarakat NTI dalam melakukan interaksi sosial. Dalam menganalisa data luasan yang ada, peneliti membagi data luasan yang didapatkan dalam 4 interval luasan yaitu: $1 \mathrm{~m}^{2}-12 \mathrm{~m}^{2}, 13 \mathrm{~m}^{2}-24 \mathrm{~m}^{2}, 25 \mathrm{~m}^{2}-36 \mathrm{~m}^{2}, 37 \mathrm{~m}^{2}-48 \mathrm{~m}^{2}$.

Dari hasil analisa didapatkan bahwa kebutuhan luasan ruang terbuka yang dominan digunakan oleh masyarakat perumahan NTI, tidak terlalu besar hanya sekitar $1-12 \mathrm{~m}^{2}$.

\subsubsection{Jarak Ruang Terbuka dari Rumah}

Definisi operasional variabel Jarak ruang terbuka yaitu dekat, agak jauh, jauh dan sangat jauh dijelaskan sebagai berikut: dekat artinya tapak tidak berhubung $(0-100 \mathrm{~m})$, agak jauh artinya terpisah 1 blok perumahan (100-300m), jauh artinya terpisah beberapa blok perumahan dan sangat jauh di sebutkan seberapa jauh (m).

Kegiatan interaksi yang dilakukan dominan pada ruang terbuka yang dekat dari rumah (51\%). Sedangkan ruang terbuka yang jauh dari rumah hanya $20 \%$. Dari hasil wawancara dengan responden, bahwa kegiatan interaksi yang dilakukan di luar rumah biasanya dilakukan dengan tetangga ataupun saudara. Dan kegiatan interaksi yang dilakukan di tepi taman yang jauh dari rumah dilakukan karena adanya kegiatan jual-beli disana yang mengundang masyarakat untuk berdatangan.

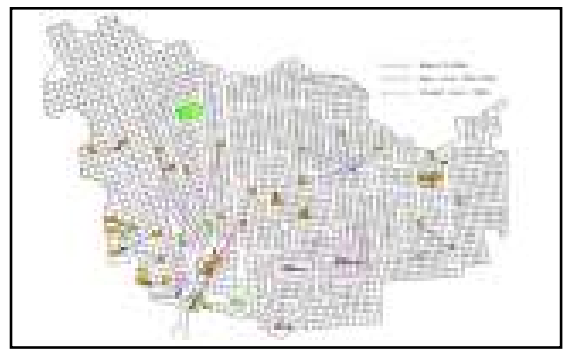

Gambar 14. Jarak Ruang Terbuka dari Rumah Responden

\subsubsection{Perabot Ruang Terbuka}

Pada beberapa jenis ruang terbuka yang digunakan, terdapat beberapa jenis ruang terbuka yang dilengkapi dengan perabot ruang terbuka, seperti tempat duduk, lampu taman dan permainan anak. Keberadaan perabot ini sangat menunjang terjadinya interaksi sosial antara masyarakat perumahan, karena ruang terbuka yang dilengkapi dengan perabot ruang terbuka akan lebih sering dikunjungi oleh masyarakat.

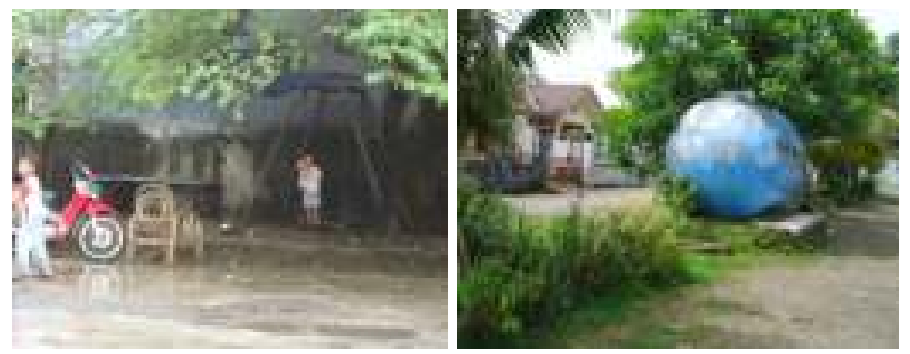

Gambar 15. Perabot Ruang Terbuka

\subsection{Kegiatan Interaksi}

\subsubsection{Jenis dan Kegiatan Interaksi}

Dari hasil pengamatan dan analisis kuisioner yang diberikan kepada responden, menghasilkan identifikasi kegiatan masyarakat perumahan NTI terdiri atas : bermain (sepakbola, sepeda, layang-layang, kelereng), bercerita, menelpon dan bertranksasi jual-beli.

Kegiatan Interaksi bercerita atau berbincang-bincang biasanya dilakukan di depan rumah responden bersama saudara atau tetangga. Kegiatan ini dilakukan dengan posisi duduk-duduk di kursi yang telah tersedia atau dibawa dari rumah atau dengan posisi berdiri dibawah pohon dengan durasi waktu 15-30 menit. Dan biasanya dilakukan pada sore hari.

Kegiatan interaksi bermain biasanya dilakukan oleh anak-anak. Di tempat yang cukup luas seperti di halaman masjid dan jalan. Pelaku kegiatan ini berjumlah 4-10 orang. 
Kegiatan bermain dilakukan pada siang sampai sore hari namun dominan pada sore hari dengan durasi waktu kegiatan 30 menit-1 jam. Adapun jenis permainan yang dilakukan ialah: bermain bola, layangan, berlari-larian dan bersepeda

Kegiatan tranksaksi jual-beli dilakukan di bagian depan perumahan tepatnya di tepi-tepi taman. Aktivitas perdagangan berlangsung dari pagi sampai malam hari dan paling ramai pada sore dan malam hari. Kegiatan tranksaksi jual-beli juga diselingi dengan kegiatan interaksi bercerita antara pembeli-pembeli dan penjual-pembeli. Durasi dari kegiatan ini biasanya 15 menit.

Kegiatan menelpon merupakan kegiatan interaksi dengan komunikasi tidak langsung. Di perumahan NTI, terdapat beberapa warga yang melakukan kegiatan ini didepan rumah dan dilakukan dengan posisi duduk ataupun berdiri.

\subsubsection{Waktu Interaksi}

Adapun waktu yang digunakan untuk melakukan kegiatan interaksi ialah pada pukul 08.00- 21.00 dan dominan pada waktu sore hari 15.01-18.00 (83\%). Waktu sore hari memang merupakan waktu yang sangat tepat untuk melakukan kegiatan interaksi karena pada waktu pagi hari, masyarakat tentu saja disibukkan dengan kegiatan rutinitas permanennya seperti berangkat kerja, mengurus rumah dan lain-lain.

\subsubsection{Durasi Interaksi}

Rentang waktu kegiatan interaksi yang dilakukan oleh masyarakat NTI di ruang terbuka terbagi atas: 15 menit30 menit, 31 menit- 45 menit dan 46 menit- 1jam. Durasi kegiatan interaksi yang dilakukan dominan ialah pada rentang 30 menit- 45menit (49\%) dan 15 menit- 30 menit (39\%). Hal ini mengindikasikan waktu yang paling optimal dilakukan di ruang terbuka, terlihat bahwa masyarakat tidak menghabiskan banyak waktu di ruang-ruang terbuka perumahan. Di samping itu, sebagian responden menggunakan waktu lebih panjang 46 menit- 1 jam (12\%). Dari hasil pengamatan peneliti, bahwa kelompok usia anak-anak yang menggunakan rentang waktu panjang tersebut. Hal ini, tentu berkaitan dengan kebiasaan anak-anak yang lebih aktif bermain di luar rumah.

\subsubsection{Intensitas kegiatan}

Menurut Gehl (1987), kegiatan interaksi sosial masyarakat selalu terjadi secara spontan. Dalam penelitian ini, juga didapatkan hasil seperti demikian, namun tidak mendominasi. Dari hasil analisis kuisioner yang di berikan kepada responden, terlihat bahwa masyarakat pengguna ruang terbuka melakukan kegiatan di ruang terbuka secara berulang-berulang. Kebanyakan kegiatan tersebut dilakukan beberapa kali dalam seminggu (55\%), dan kegiatan yang terjadi secara spontan (36\%). Hal ini menjelaskan bahwa sudah keterikatan personal antara ruang terbuka dengan kegiatan yang dilakukan oleh masyarakat perumahan NTI.

\subsection{Hubungan Ruang Terbuka dengan Kegiatan Interaksi}

Setelah mendiskripsikan hubungan antar variabel satu persatu, selanjutnya peneliti variabel mana yang paling signifikan mempengaruhi terjadinya interaksi sosial. Berikut adalah tabel hasil analisa dengan menampilkan nilai $\mathrm{C}$ (koefisien kontingensi) antara variabel $\mathrm{X}$ dan $\mathrm{Y}$ yang di dapatkan dengan menggunakan analisa khi kuadrat di software SPSS.

Tabel 1. Hubungan Karakteristik Ruang Terbuka dengan Interaksi

\begin{tabular}{|c|c|c|c|c|c|}
\hline \multirow[b]{2}{*}{ Variabel } & \multirow{2}{*}{$\begin{array}{c}\text { Karakteristik } \\
\text { Ruang } \\
\text { Terbuka } \\
\text { (X1) }\end{array}$} & \multicolumn{4}{|c|}{ Interaksi Sosial (Y) } \\
\hline & & $\begin{array}{c}\text { Kegiatan Interaksi } \\
\text { (Y1) }\end{array}$ & $\begin{array}{c}\text { Waktu Interaksi } \\
\text { (Y2) }\end{array}$ & $\begin{array}{l}\text { Durasi Interaksi } \\
\text { (Y3) }\end{array}$ & $\begin{array}{c}\text { Intensitas Interaks } \\
\text { (Y4) }\end{array}$ \\
\hline X.1.1 & $\begin{array}{l}\text { Letak Ruang } \\
\text { Terbuka } \\
\end{array}$ & 0.002 & 0.209 & 0.000 & 0.003 \\
\hline X.1.2 & $\begin{array}{l}\text { Luasan Ruang } \\
\text { Terbuka }\end{array}$ & 0.005 & 0.415 & 0.017 & 0.001 \\
\hline X.1.3 & $\begin{array}{l}\text { Jarak dari } \\
\text { Rumah }\end{array}$ & 0.002 & 0.017 & 0.013 & 0.303 \\
\hline X.1.4 & $\begin{array}{l}\text { Perabot Ruang } \\
\text { Terbuka }\end{array}$ & 0.064 & 0.020 & 0.068 & 0.940 \\
\hline
\end{tabular}

Nilai C (koefisien kontingensi) yang dianggap berhubungan erat ialah $>0.05$. Jadi jika terdapat nilai $\mathrm{C}$ dari dua variabel yang $>0.05$ maka kedua variabel itu diragukan memiliki hubungan yang signifikan.

Dari tabel nilai signifikansi variabel diatas, dapat terlihat bahwa kegiatan interaksi (Y1) secara signifikan mempengaruhi letak ruang terbuka (X1.1), luasan ruang terbuka (X1.2), dan jarak ruang terbuka dari rumah (X1.3). Waktu Interaksi secara signifikan mempengaruhi jarak ruang terbuka dari rumah (X1.3). Durasi interaksi (Y1) berpengaruh signifikan dengan letak ruang terbuka (X1.1), luasan ruang terbuka (X1.2), dan jarak ruang 
terbuka dari rumah (X1.3). Intensitas interaksi secara signifikan mempengaruhi letak ruang terbuka (X1.1) dan luasan ruang terbuka $(\mathrm{X} 1.2)$

Tabel 2. Hubungan Karakteristik Responden dengan Interaksi Sosial

\begin{tabular}{cccccc}
\hline \multirow{2}{*}{ Var. } & $\begin{array}{c}\text { Karakteristik } \\
\text { Responden } \\
(\mathrm{X} 2)\end{array}$ & $\begin{array}{c}\text { Kegiatan Interaksi } \\
(\mathrm{Y} 1)\end{array}$ & $\begin{array}{c}\text { Waktu Interaksi } \\
(\mathrm{Y} 2)\end{array}$ & $\begin{array}{c}\text { Durasi Interaksi } \\
(\mathrm{Y} 3)\end{array}$ & $\begin{array}{c}\text { Intensitas Interaksi } \\
(\text { Y4) }\end{array}$ \\
\cline { 3 - 6 } & Jenis Kelamin & 0.557 & 0.518 & 0.672 & 0.396 \\
\hline $\mathrm{X} .2 .1$ & Usia & 0.000 & 0.013 & 0.466 & 0.089 \\
\hline $\mathrm{X} .2 .2$ & Pekerjaan & 0.060 & 0.234 & 0.383 & 0.000 \\
\hline $\mathrm{X} .2 .3$ & & & & & \\
\hline
\end{tabular}

Dari tabel nilai signifikansi variabel diatas, dapat terlihat bahwa kegiatan interaksi (Y1) secara signifikan mempengaruhi usia responden (X2.1). Waktu Interaksi secara signifikan mempengaruhi usia responden (X2.2). Durasi interaksi (Y1) tidak secara signifikan mempengaruhi karakteristik responden. Intensitas- interaksi secara signifikan mempengaruhi Pekerjaan responden (X1.2)

\section{Kesimpulan}

Dari hasil analisis data yang telah dilakukan dapat disimpulkan sebagai berikut:

Karakteristik ruang terbuka yang digunakan oleh masyarakat untuk melakukan interaksi sosial ialah: letaknya di depan rumah, halaman masjid, tepi taman, jalan dan tanah kosong. Jaraknya dari rumah sekitar 0- $100 \mathrm{~m}$, adapun yang lebih jauh yaitu sekitar $300 \mathrm{~m}$ dari rumah digunakan karena adanya faktor jual-beli pada daerah tersebut. Luasan ruang terbuka yang dominan digunakan ialah sekitar $0-12 \mathrm{~m}^{2}$. Perabot ruang terbuka seperti: lampu taman dan tempat duduk dan pohon peneduh.

Jenis interaksi sosial yang dilakukan oleh masyarakat perumahan NTI ialah interaksi sosial asosiatif dengan kegiatan seperti: bercerita, bermain, menelpon dan bertranksaski jual beli. Adapun intensitas kegiatan interaksi yang dilakukan ialah dominan beberapa kali seminggu dengan durasi kegiatan sekitar 15-30 menit.

Variabel karakteristik ruang terbuka dan karakteristik responden yang signifikan bepengaruh terhadap terjadinya interaksi sosial ialah letak ruang terbuka tersebut, jarak ruang terbuka dari rumah, luasan ruang terbuka dan perabot ruang terbuka.

\section{Daftar Pustaka}

Barliana, Syaom. (2010). Arsitektur, Komunitas dan Modal Sosial. Metatekstur Gehl, J. (1987). The Life Between Buildings. New York : Van Nostrand Reinhold.

Suryabrata, S. (1983). Metodologi Penelitian, Manajemen. Jakarta: PT Rajagrafindo Persada

Whyte, W. H. (1979). The Social Life of Small Urban Spaces. Washington, DC: The Conservation Foundation. 


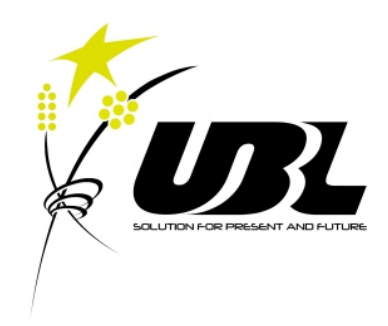

Published:

Program Studi Arsitektur Fakultas Teknik Universitas Bandar Lampung 